\title{
WHEAT GENOTYPES AS AFFECTED BY TERMINAL HEAT STRESS IN NORTHERN BANGLADESH
}

\author{
P. Bala ${ }^{*}$ and S. Sikder ${ }^{2}$ \\ ${ }^{1}$ Department of Agriculture, Hazi Lalmia City College, Gopalganj, Bangladesh. \\ ${ }^{2}$ Department of Crop Physiology and Ecology, Hajee Mohammad Danesh Science and Technology University, \\ Dinajpur, Bangladesh \\ ${ }^{*}$ Corresponding author, E-mail: kbdpronay@ yahoo.com
}

(Received: 20 June 2017, Accepted: 20 April 2018)

Keywords: Cereal crops; Yield attributes, High temperature; Climate change

\begin{abstract}
This study was conducted in Crop Physiology and Ecology research field of Hajee Mohammad Danesh science and Technology University, Dinajpur during the two successive years of 2011-12 and 2012-13 to identify morpho-physiological attributes of wheat genotypes in response to terminal heat stress. In this respect, three sowing dates at November 27 (normal), December 17 (late) and January 7 (very late growing condition) and eight wheat genotypes viz., Pavon-76, Prodip, BARI Gom-25, BARI Gom-26, BAW-1143, BAW-1146, BAW-1147 and BAW-118 were evaluated. Growth and morphological changes of wheat genotypes were evaluated in relation to heat tolerance in field condition. Growth attributes such as LAR, SLA and LWR for all the genotypes declined throughout the advancement of growth stages in both the growing seasons and at heat stress condition values of all the parameters such as plant height and grain yields were reduced compared to normal condition.
\end{abstract}

\section{Introduction}

Wheat provides $21 \%$ of food calories and $20 \%$ of protein for more than 4.5 billion people worldwide (Barun et al., 2010). It is grown on about 218.5 million hectare in a wide range of environments, with annual production of about 712.31 metric tons (FAO, 2014). Continual heat stress (mean daily temperature of over $17.5^{\circ} \mathrm{C}$ in the coolest month of the season) affects approximately 7 million hectares of wheat in developing countries, while terminal heat stress is a problem in $40 \%$ of temperate environments, which cover 36 million hectares (Reynolds et al., 2010). Heat is a non-uniform phenomenon that negatively influences plant growth, morphology, physiology and yield depending upon crop developmental stage, time, and severity of stress (Ahmed and Prasad, 2011). Crops at various growth stages require variable level of temperature for optimum growth. Plants have limited nutrient uptake capacity and photosynthetic efficiency under heat stress. This stress can also reduce organ size (leaf, tiller and spikes) and growth period for various development stages at tillering, booting, heading, anthesis and grain filling stages (Hossain et al., 2013). Plant sensitively to high temperature results in disturbed metabolic process coupled with lower plant biomass accumulation (Hasanuzzaman et al., 2013).

In Bangladesh the optimum time for wheat cultivation lies within November. However, farmers often sow the seeds late even at the end of December due to late harvesting of previous crop, i.e. aman rice (summer rice). Consequently, the wheat plant experiences much higher temperature than the optimum at the reproductive phase of growth. High temperature at the terminal growth stage causes lower growth and yield. However, there might have varietal differences in growth and yield performance under high temperature conditions. Therefore, this experiment was carried out to select suitable wheat genotypes for growing under late sowing conditions. 


\section{Materials and Methods}

The experiment was conducted in the research field of Crop physiology and Ecology Department, Hajee Mohammad Danesh Science and Technology University, Dinajpur, Bangladesh from November to April of 2011-12 and 2012-2013. Seeds were sown on 27 November (Normal), 17 December (Late) and 7 January (Very late) in main plot and eight genotypes viz. Prodip, BARI Gom-25, BARI Gom-26, BAW-1143, BAW-1146, BAW-1147, BAW-1148 and Pavon-76 in sub-plot as experimental materials. The experimental design was a split- plot with three three replications with plot size $2.5 \mathrm{~m} \mathrm{x} 4 \mathrm{~m}$. Three irrigations were applied at CRI, flowering and grain filling stage. In all sowing dates, at each harvest, the plants were cut off at the ground level and the tops were separated into leaves, stem and panicle (if present) at 10 days interval with start of 20 days after sowing. The harvested plant parts were kept in an electrical oven at about at $70^{\circ} \mathrm{C}$ for 72 hours and the dry weights of these parts were taken by an electrical balance. Leaf area was determined as function of length maximum width $\times 0.75$ (Mossad et al. 1995).

From the dry weight of different plant parts and leaf area data, the following growth attributes were calculated between two successive harvests according to the classical technique of growth analysis (Radford 1967).

1. Leaf area ratio $(L A R)=\frac{\left(\log _{e} W_{2}-\log _{e} W_{1}\right)\left(L A_{2}-L A_{1}\right)}{\left(W_{2}-W_{1}\right)\left(\log _{e} L A_{2}-\log _{e} L A_{1}\right)}$

2. Specific leaf area (SLA) $=\frac{\text { Leaf area }}{\text { Leaf dry weight }}$

3. Leaf weight ratio $($ LWR $)=\frac{\text { Leaf dry weight }}{\text { Total plant dry weight }}$

Where, $\mathrm{W}_{2}$ and $\mathrm{W}_{1}$ are the total dry weights, $\mathrm{LA}_{2}$ and $\mathrm{LA}_{1}$ are the total leaf area per plant at $\mathrm{t}_{2}$ and $t_{1}$, the later and the former harvest, respectively.

Plant height was measured from base of plant to the tip of spike excluding awn with the help of a measuring scale. Ten plant samples from each plot were taken and mean was calculated. The data were analyzed by using MSTAT-C computer package. The treatment means were compared using Duncan's Multiple Range Test (DMRT).

\section{Results and discussion}

\section{Leaf Area Ratio (LAR)}

Leaf area ratio (LAR) was declined steadily with increasing plant age of all the genotypes for each growing condition of both the years. (Fig. 1 and Fig. 2). LAR of all the genotypes started from a higher value at the initial stage of growth and then declined throughout the successive days after sowing in each growing condition in both the years. 


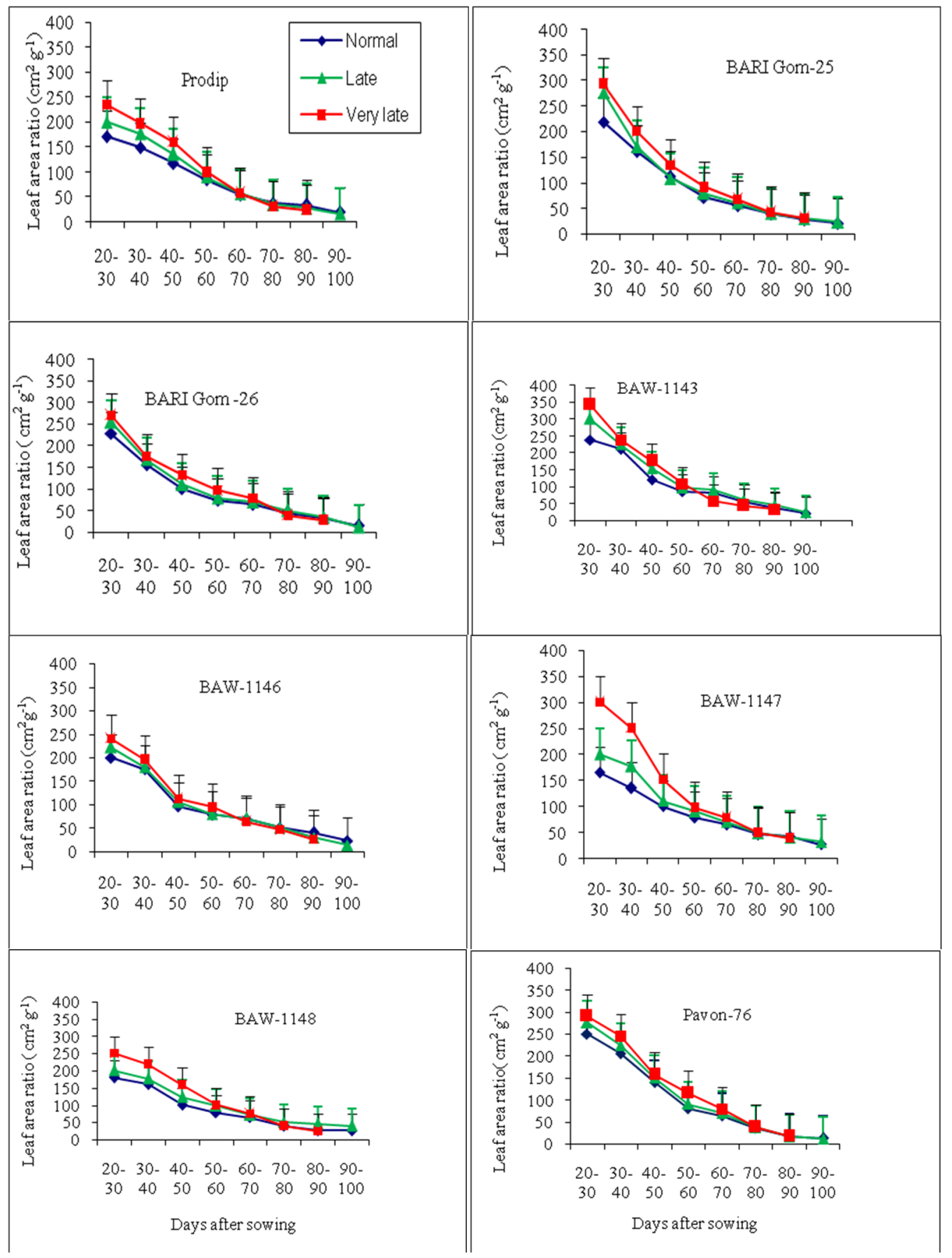

Fig. 1. Effect of sowing time on leaf area ratio (LAR) of eight wheat genotypes at different days after sowing from original values (2011-12). Vertical bars indicate SE (+) value. 


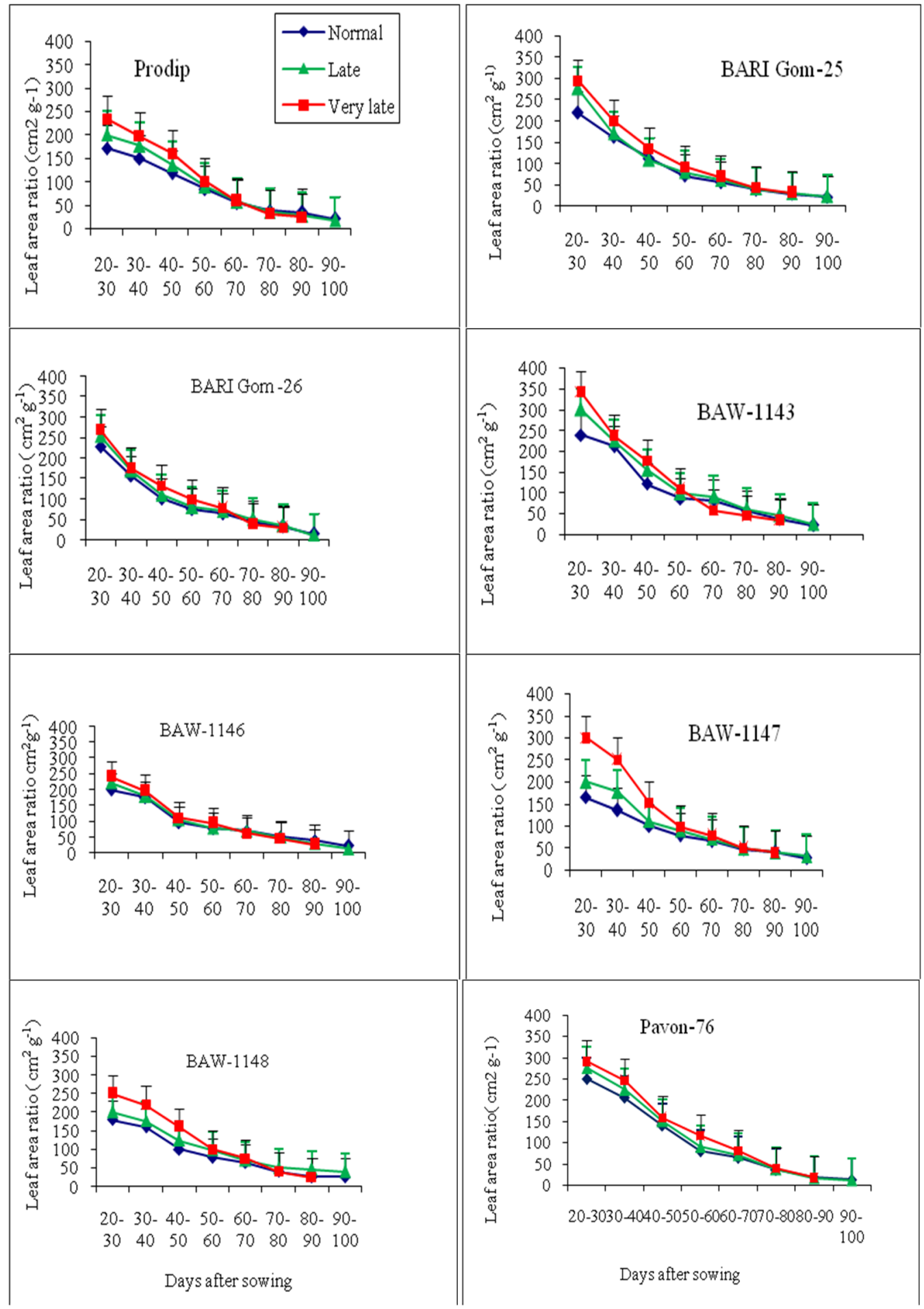

Fig. 2. Effect of sowing time on leaf area ratio (LAR) of eight wheat genotypes at different days after sowing from original values (2012-13). Vertical bars indicate SE $(\underline{+})$ value. At normal growing condition of both the years, BAW-1143 had the highest LAR at the initial stage (20-30 DAS), whereas Pavon-76 showed the lowest LAR at that growing stage (20-30 
DAS). In both late and very late growing conditions, at the initial stage all the genotypes showed higher LAR compared to normal growing condition except Pavon-76 in both the years.

Haider (2007) observed that LAR was highest during the early vegetative stage but later decreased rapidly with the advancement of plant age, possibly due to abscission of older leaves. Similar results were reported by Pandy et al. (2000).

In fast growing species allocated more carbon to leaves than slow-growing species and that higher LAR in fast-growing species allows plants to fix more carbon per unit plant weight.

\section{Specific Leaf Area (SLA)}

Specific leaf area (SLA) of eight wheat genotypes at normal, late and very late growing condition of both the years are shown (Fig. 3 and Fig. 4). At the early stage of growth, all the genotypes started from higher values of SLA and then declined gradually in each growing condition of both the years.

In each growing conditions, it was found that genotypes e.g. BAW-1143, BARI Gom -25, BARI Gom-26 and Prodip showed higher SLA and genotype Pavon-76 always showed the lowest.

Specific leaf area (SLA) of eight wheat genotypes for each of the growing conditions declined throughout the advancement of growth stages in both the years. The normal growing plants had higher SLA than those of late growing plants in both the years.

Haque (2000) found higher SLA in some wheat genotypes than the others and timely sown wheat plants showed higher SLA than the delayed sowing plants. The decline of SLA with age was reported by Sarker and Paul (1998) in wheat. SLA values decreased with increasing plant dry weight. Lower value of SLA was found in the late and very late sown plants of all the eight genotypes. This result is in agreement with Haider (2007) in wheat.

\section{Leaf Weight Ratio (LWR)}

Leaf weight ratio (LWR) showed higher values at the early stages of growth and thereafter declined with increasing plant age for all the genotypes in both the growing conditions and years (Fig. 5 and 6).

Under very late growing condition all the genotypes had higher LWR at the early stages of growth and then declined gradually with increasing plant age. Under late growing condition, all the genotypes had higher LWR value compared to normal growing condition at all the DAS with a few exceptions for genotypes BAW-1146, BAW-1147, BAW-1148 and genotype Pavon76. At $40 \mathrm{DAS}$, the normal growing condition for LWR values of BAW-1146, BAW-1147, BAW-1148 and Pavon-76 were higher compared to their respective late growing conditions. Under normal growing condition of both the years, BAW-1143, BARI Gom-25, BARI Gom-26 and Prodip showed comparatively lower LWR at all the DAS compared to other genotypes.
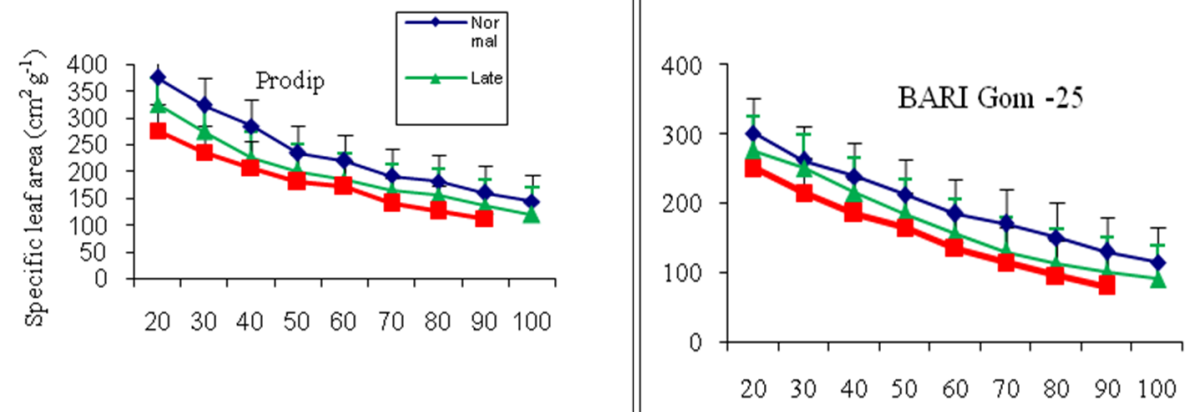

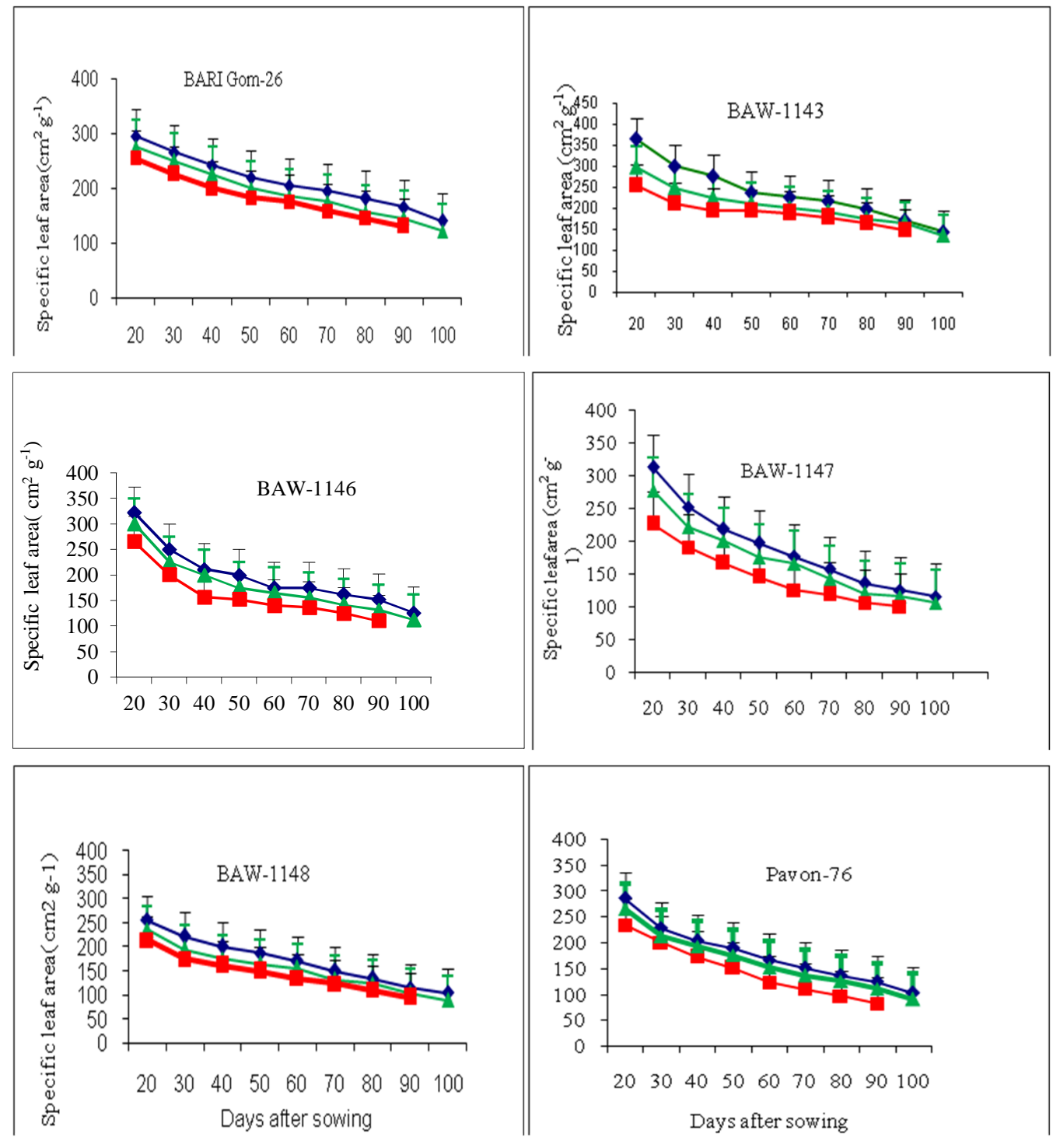

Fig. 3. Effect of sowing time on specific leaf area (SLA) of eight wheat genotypes at different days after sowing from original values (2011-12). Vertical bars indicate $S E( \pm)$ value.
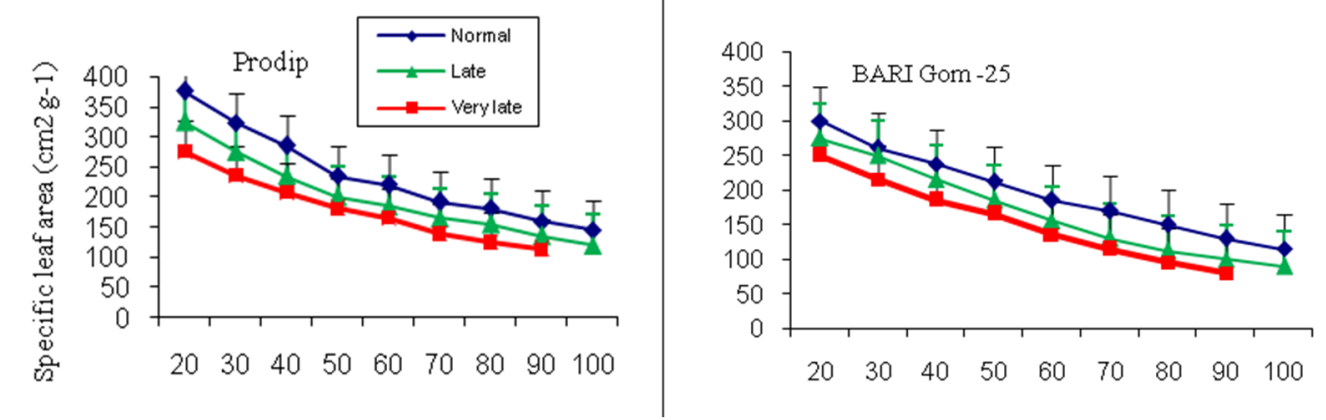

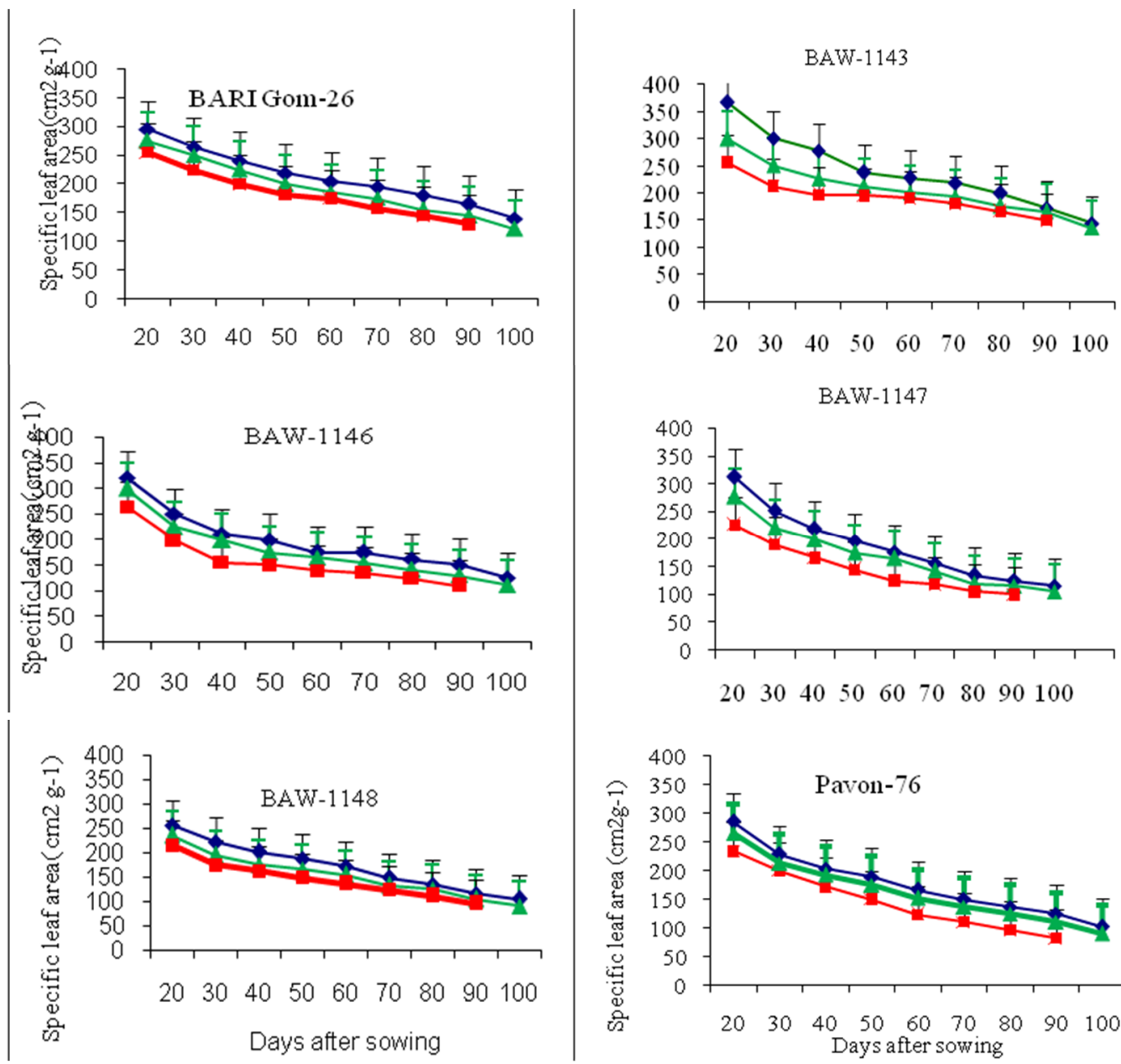

$\begin{array}{lllllllll}20 & 30 & 40 & 50 & 60 & 70 & 80 & 90 & 100\end{array}$

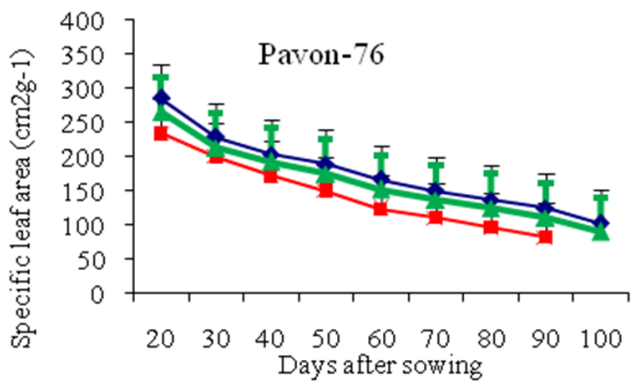

Fig. 4. Effect of sowing time on specific leaf area (SLA) of eight wheat genotypes at different days after sowing from original values (2012-13). Vertical bars indicate SE \pm value.

Saha and Paul (1995) studied LWR in wheat and reported that the sharp decrease in LWR at the later stages might be due to the sharp increase of TDM. This result was also supported by Haque (2000), Sarker and Paul (1998), Nahar and Paul (1998) in wheat. In the present investigation, the late growing plants had higher LWR than those of the normal growing plants in both the years because of lower TDM in the late growing condition throughout the whole growth period. High temperature prevailing at the later stages of late growing condition produced lower TDM. High temperature depressed the mean overall LWR during the later part of the growing period. Haider (2007) also stated that with increasing plant age in all the varieties and sowing dates LWR was downward drifts. 


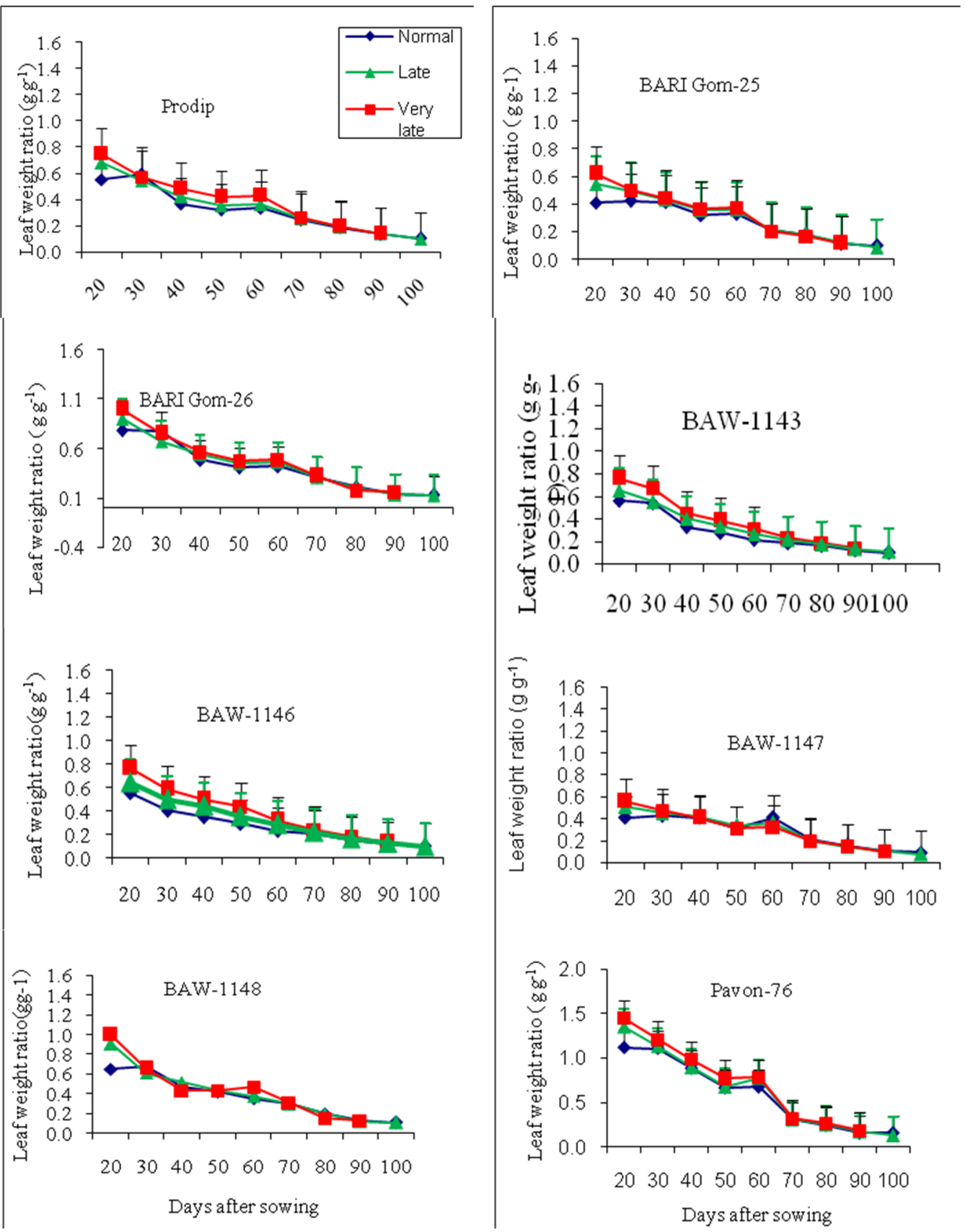

Fig. 5. Effect of sowing time on leaf weight ratio (LWR) of eight wheat genotypes at different days after sowing from original values (2011-12). Vertical bars indicate SE $( \pm)$ value. 

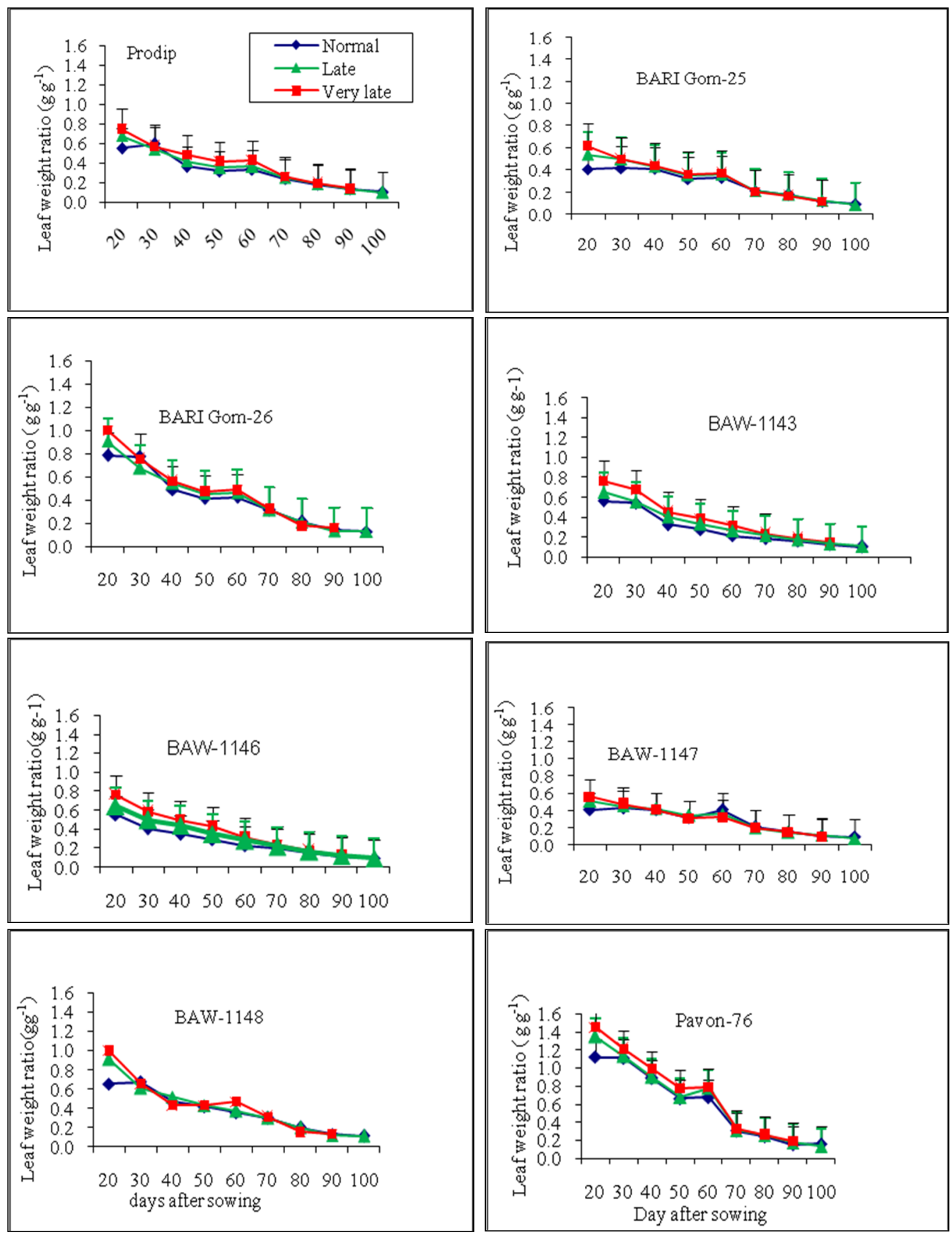

Fig. 6. Effect of sowing time on leaf weight ratio (LWR) of eight wheat genotypes at different days after sowing from original values (2012-13). Vertical bars indicate SE $( \pm \underline{)}$ value.

\section{Plant height}

Plant height of eight wheat genotypes at different growing conditions are presented in Tables 1 and 2. From the results, it was observed that the combined effect of growing condition and wheat genotypes on plant height was significant in both the years. 
Under normal growing condition, BAW-1146 attained the highest plant height $(103.00 \mathrm{~cm}$ and $104.67 \mathrm{~cm}$ for first and second year, respectively). The heat sensitive genotype Pavon-76 attained the lowest plant height $(93.53 \mathrm{~cm}$ and $95.00 \mathrm{~cm}$ for first and second year respectively). Under late and very late growing conditions, plant height was markedly reduced for all the wheat genotypes in different magnitudes. Plant height varied under late sowing and very late sowing due to genotype and the combined effect of growing condition. The decrease in plant height may have occurred due to shortening of growth and photosynthetic period imposed by heat stress in a late sown environment. These results coincide with the findings of Mishra et al. (2000), and Ubaidullah et al. (2006) who observed significant negative effects of delayed planting on plant height in wheat. Irfan et al. (2005) also reported reduction in plant height of wheat genotypes due to late sowing and high temperature stress. Wheat varieties showed a significant effect of varieties on plant height (Mattas et al., 2011 and Mohammad et al., 2011) and varied greatly among various wheat genotypes (Ford and Throne, 2001). The differences in plant height due to various genotypes might be due to varied genetic condition of genotypes

Table 1. Plant height $(\mathrm{cm})$ of eight wheat genotypes under normal, late and very late growing conditions in 2011-12

\begin{tabular}{|c|c|c|c|c|}
\hline \multirow[b]{2}{*}{ Genotypes } & \multicolumn{3}{|c|}{ Plant height $(\mathrm{cm})$} & \multirow{2}{*}{$\begin{array}{l}\text { Reduction }(\%) \text { at very } \\
\text { late growing condition } \\
\text { compared to normal }\end{array}$} \\
\hline & $\begin{array}{l}\text { Normal growing } \\
\text { condition } \\
\text { (27 Nov.) }\end{array}$ & $\begin{array}{l}\text { Late growing } \\
\text { condition } \\
\text { (17 Dec.) }\end{array}$ & $\begin{array}{l}\text { Very late growing } \\
\text { condition ( } 7 \text { Jan.) }\end{array}$ & \\
\hline Prodip & $99.00 \mathrm{c}$ & $93.56 \mathrm{~d}$ & 86.45gh & 12.68 \\
\hline BARI Gom-25 & $99.58 \mathrm{bc}$ & 93.66d & $86.22 \mathrm{gh}$ & 13.42 \\
\hline BARI Gom-26 & $100.02 \mathrm{ac}$ & $94.44 d$ & 87.00fh & 13.02 \\
\hline BAW-1143 & $101.20 \mathrm{ac}$ & $95.00 \mathrm{~d}$ & $88.00 \mathrm{eg}$ & 13.04 \\
\hline BAW-1146 & $103.00 \mathrm{a}$ & $97.00 \mathrm{~d}$ & $90.00 \mathrm{e}$ & 12.62 \\
\hline BAW-1147 & $102.00 \mathrm{ab}$ & $96.00 \mathrm{~d}$ & $89.00 \mathrm{ef}$ & 12.75 \\
\hline BAW-1148 & $102.00 \mathrm{ab}$ & $96.00 \mathrm{~d}$ & $89.22 \mathrm{ef}$ & 12.53 \\
\hline Pavon-76 & $93.53 \mathrm{~d}$ & $84.89 \mathrm{~h}$ & $76.32 \mathrm{i}$ & 18.40 \\
\hline
\end{tabular}

Mean followed by same letter(s) did not differ significantly at 5\% level of significance by DMRT

Table 2. Plant height of eight wheat genotypes under normal, late and very late growing conditions in 2012-13

\begin{tabular}{lcccc}
\hline Genotypes & \multicolumn{3}{c}{ Plant height $(\mathrm{cm})$} & $\begin{array}{c}\text { Reduction (\%) at } \\
\text { very late growing } \\
\text { condition compare } \\
\text { to normal }\end{array}$ \\
\cline { 2 - 4 } $\begin{array}{c}\text { Normal growing } \\
\text { condition } \\
\text { (27 Nov.) }\end{array}$ & $\begin{array}{c}\text { Late growing } \\
\text { condition } \\
\text { (17 Dec.) }\end{array}$ & $\begin{array}{c}\text { Very late growing } \\
\text { condition } \\
(7 \mathrm{Jan} .)\end{array}$ & 10.37 \\
\hline Prodip & $100.02 \mathrm{c}$ & $95.00 \mathrm{~d}$ & $89.65 \mathrm{eh}$ & 12.87 \\
BARI Gom-25 & $100.14 \mathrm{c}$ & $94.67 \mathrm{~d}$ & $87.25 \mathrm{hi}$ & 13.47 \\
BARI Gom-26 & $100.50 \mathrm{c}$ & $91.67 \mathrm{ef}$ & $87.00 \mathrm{hj}$ & 12.32 \\
BAW-1143 & $101.50 \mathrm{bc}$ & $91.00 \mathrm{eg}$ & $89.00 \mathrm{fh}$ & 14.02 \\
BAW-1146 & $104.67 \mathrm{a}$ & $95.00 \mathrm{~d}$ & $92.00 \mathrm{e}$ & 14.47 \\
BAW-1147 & $103.67 \mathrm{ab}$ & $96.00 \mathrm{~d}$ & $88.67 \mathrm{gh}$ & 17.40 \\
BAW-1148 & $103.33 \mathrm{ab}$ & $95.00 \mathrm{~d}$ & $85.33 \mathrm{ij}$ & 15.79 \\
Pavon-76 & $95.00 \mathrm{~d}$ & $86.33 \mathrm{j}$ & $81.00 \mathrm{k}$ & \\
\hline CV $(\%)$ & \multicolumn{5}{|c|}{} \\
\hline
\end{tabular}

Mean followed by same letter(s) did not differ significantly at $5 \%$ level of significance by DMRT

\section{Grain yield}

At very late growing condition, the grain yield of all the genotypes was reduced more. Comparatively genotypes BAW-1143, BARI Gom-26, BARI Gom-25 and Prodip (42.00 to 
$50.97 \%$ and 42.71 to $50.59 \%$ for the first and second year, respectively) showed lower reduction of grain yield than the MHT genotypes and HS genotype Pavon-76.

Regarding relative performance, genotypes BAW-1143, BARI Gom-26, BARI Gom-25 and Prodip also attained higher relative grain yield (49 to $58 \%$ for both the year) than the genotypes Pavon-76 (Fig. 4).

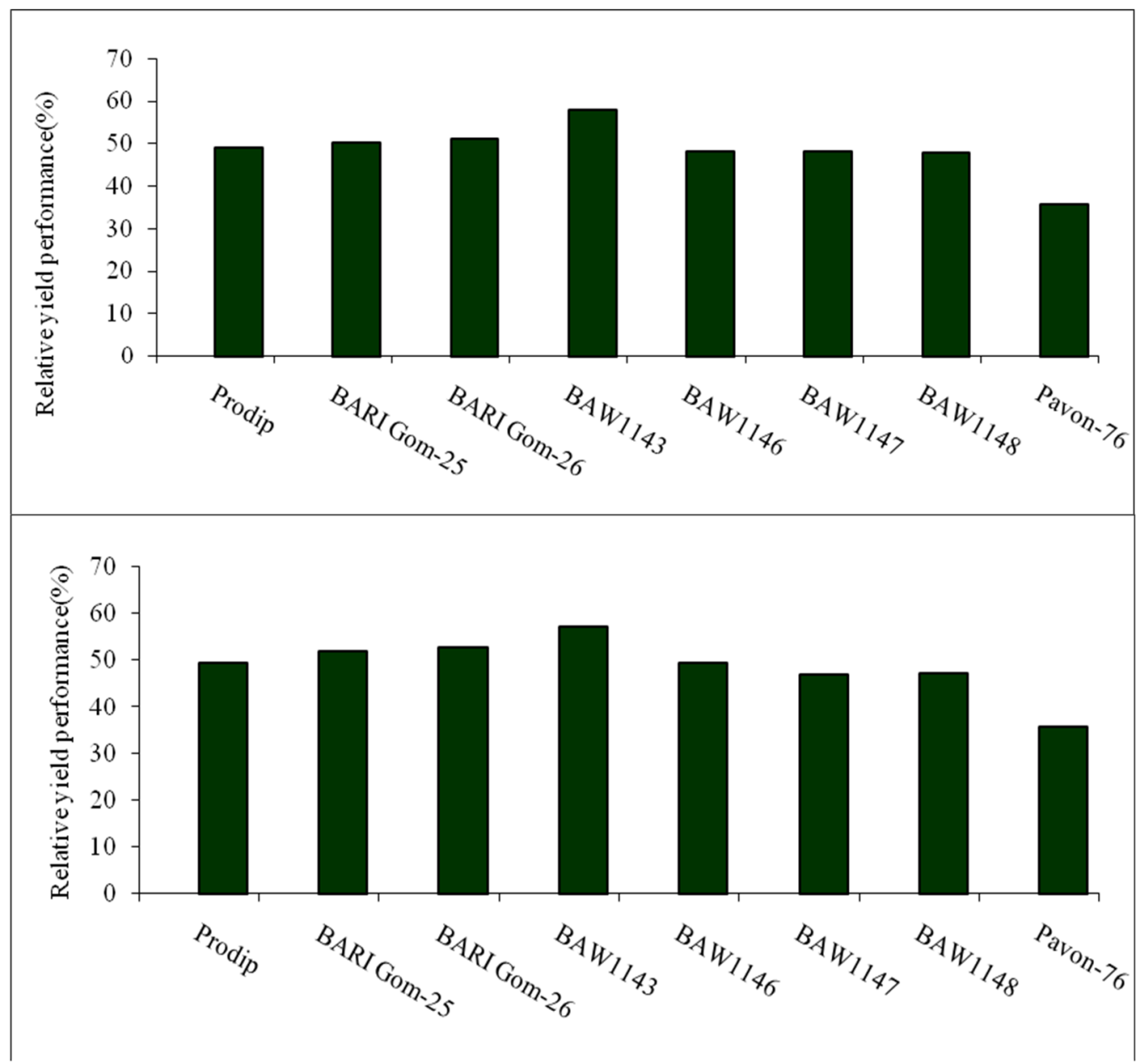

Fig. 4: Relative grain yield (\%) of different wheat genotypes in 2011-12 (upper graph) and 2012-13 (lower graph) compared normal to very late.

However, genetic effects are not independent of environmental effects; most genotypes do not perform satisfactorily in all environments. When an interaction between a genotype and the environment occurs, the relative ranking of genotypes for yield often differs when genotypes are compared over a series of environments and/or years (Al-Otayk, 2010).

In Bangladesh, early wheat faces high temperature stress at the vegetative stage and late sowing wheat is affected at two stages: germination by low temperature stress $\left(<10^{\circ} \mathrm{C}\right)$ and at the reproductive stage by high temperature $\left(>25^{\circ} \mathrm{C}\right)$, which ultimately affects grain yield (Hossain $e t$ al. 2011; 2012).

\section{Conclusion}


Genotypes BAW-1143, BARI Gom-25, BARI Gom-26 and Prodip showed higher SLA compared to genotypes BAW-1146, BAW-1147, and BAW-1148. However, genotype Pavon-76 always showed the lowest SLA at all the DAS and sowing times compared to the other genotypes. Under late and very late growing condition all the genotypes had higher LWR at the early stages of growth and then declined gradually with increasing plant age. In this condition at 40 DAS, the normal growing condition for LWR values of BAW-1146, BAW-1147, BAW1148 and Pavon-76 were higher compared to their respective late growing condition. Under normal growing condition of both the years, BAW-1143, BARI Gom-25, BARI Gom-26 and Prodip showed comparatively lower LWR at all the DAS compared to other genotypes. LAR of all the genotypes started from a higher value at the initial stages of growth and then declined throughout the successive days after sowing in each growing condition both the years. In late and very late growing condition, at the initial stage all the genotypes showed higher LAR compared to normal growing condition except Pavon-76 in both the years. At this initial stage, again BAW-1143 attained the highest LAR and Pavon-76 showed the lowest LAR. Plant height was found higher late and very late growing condition. Genotypes BAW-1143, BARI Gom-25, BARI Gom-26 and Prodip showed higher relative grain yield than that of BAW-1146, BAW1147 and BAW-1148

\section{References}

Ahmad, P. and M. N. V. Prasad. 2011. Abiotic stress responses in plants metabolism, Productivity and sustainability. New York, NY: Springer Sciences \& Business Media.

Al-Otayk, S. M. 2010. Performance of yield and stability of wheat genotypes under high stress environments of the central region of Saudi Arabia. JKAU: Met., Env. Arid Land Agric. Sci. 21 (1), 81-92.

Barun, H. J., G. Atlin and T. Payne. 2010. Multilocation testing as a tool to identify plant response to global climate change. In: Climate change and crop production, Reynolds, C. R. P. (Ed.), pp. 34-78. CABI, London, U K.

FAO. 2014. FAO Statistical Year book 2014.World Food and Agriculture. Food and Agriculture Organization of the united nations, Rome Italy.pp34-56.

Ford, M. A. and G. N. 2001. Effect of variation in temperature and light intensity at different times on growth and yield of spring wheat. Ann. Appl.Biol., 88: 182-219.

Haider, S. A. 2007. Growth analysis in relation to sowing dates in four varieties of wheat: a functional approach. J. Life Earth Sci. 2 (2): 17-25.

Haque, M. M. 2000. Physiological analysis of yield of wheat (Triticum aestivum L.) in relation to sowing date. Ph. D. thesis. University of Rajshahi, Bangladesh.

Hasanuzzaman, M., K. Nahar, M. M. Alam, R. Roychowdhury and M. Fujita. 2013. Physiological, biochemical and molecular mechanisms of heat stress tolerance in plants.Int.j.mol.Sci.14.9643-9684.

Hossain, A., M. A. Z. Sarker, M. A. Hakim, M. V. Lozovskaya and V. P. Zvolinsky. 2011. Effect of temperature on yield and some agronomic characters of spring wheat (Triticum aestivum $\mathrm{L}$.) genotypes. Int. J. Agril. Res. Innov. Technol.1 (1\&2): 44-54.

Hossain, A. And J. A. Teixeira da Silva. 2012. Phenology, growth and yield of three wheat (Triticum aestivum L.) varieties as affected by high temperature stress. Not.Sci.Biol. 4(3): 97-106.

Hossain, A., M. sarker, M. Saifuzzaman, I. Teixeita da Silva, M. Lozovskaya and M. Akhter.2013.Evaluation of growth, yield, relative performance and heat susceptibility of 
eight wheat (Triticum aestivum L.) varietiesas affected by high temperature stress. Notular Sci.Biol.4:97-109.

Irfan, M., T. Muhammad, M. Amin and A. Jabbar. 2005. Performance of yield and other agronomic characters of four wheat genotypes under natural heat stress .Int.J. Bot. 1(2): 124-127.

Mattas, K. K., R. S. Uppal and R.P. Singh. 2011. Effect of varieties nd nitrogen management on the growth, yield and noitrogen uptake of durum wheat. Res. J. Agric. Sci. 2: 376-380.

Mishra, D. K., R. A. Khan and M.S. Baghel. 2000. Stability of wheat varieties under various dates of sowing. Ann. Agric. Res. 21: 564-566.

Mohammad, F., I. Ahmed, N. U. Khan, K. Maqbool, A. Naz, S. Shaheen and K. Ali. 2011. Comparative study of morphological traits in wheat and triticale.Pakistan J. Bot. 43: 13031310.

Mossad, M., G. Ortiz-Ferrara, V. Mahalakshmi, and R. A. Fischer. 1995. Phyllochron response to vernalization and photoperiod in spring wheat. Crop Sci. 35: 168-171.

Nahar, N. and N. K. Paul. 1998. Growth analysis of wheat genotypes under differentsoil moisture regimes. Bangladesh J. Agril. Res. 23: 54-57.

Pandy, I. B., R. K. Pandy, D. K. Dwivedi and R.S. Singh. 2010. Phenology,heat unit requirement and yield of wheat varieties under different crop-growing environment. Indian J. Agric. Sci. 80:136-140.

Radford, P. J. 1967. Growth analysis formulae- their use and abuse. Crop Sci. 7: 171-175.

Reynolds, M. P., D. Hays and S. Chapman. 2010. Breeding for adaptation to heat and drought stress.In: Climate change and crop production, C. R. P. Reynolds, (Eds), pp. 23-65. CABI, and London, UK.

Saha, S. K. and N. K. Paul. 1995. Growth of five wheat cultivars as affected by soil moisture. J. Bio.Sci. 3: 103-112.

Sarker, A. M and N. K. Paul. 1998. Studies on growth attributes of wheat under irrigated and rainfed conditions. Bangladesh J. Bot. 27: 119-126.Shewry, P. R. 2009. Wheat. J. Exp. Bot. 60(6): 1537-1553.

Ubaidullah, R., T. Mohammad, H. S. Ali and A. W. Nassimi. 2006. Screening of wheat (Triticum aestivum L.) genotypes for some important traits against natural terminal heat stress. Pakistan J. Boil. Sci.9:2069-2075. 